\title{
Front Matter: Volume 9989
}

, "Front Matter: Volume 9989," Proc. SPIE 9989, Technologies for Optical Countermeasures XIII, 998901 (14 December 2016); doi: 10.1117/12.2264055

SPIE. Event: SPIE Security + Defence, 2016, Edinburgh, United Kingdom 


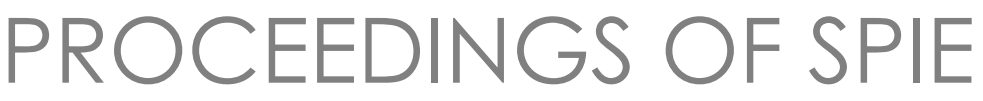

\title{
Technologies for Optical Countermeasures XIII
}

\author{
David H. Titterton \\ Robert J. Grasso \\ Mark A. Richardson \\ Editors
}

27-28 September 2016

Edinburgh, United Kingdom

Sponsored by

SPIE

Cooperating Organisations

Innovation Centre for Sensor and Imaging Systems (United Kingdom)

ADS Scotland (United Kingdom)

The Knowledge Transfer Network (United Kingdom)

Visit Scotland (United Kingdom)

European Regional Development Fund (Belgium)

Technology Scotland (United Kingdom)

Published by

SPIE 
The papers in this volume were part of the technical conference cited on the cover and title page. Papers were selected and subject to review by the editors and conference program committee. Some conference presentations may not be available for publication. Additional papers and presentation recordings may be available online in the SPIE Digital Library at SPIEDigitallibrary.org.

The papers reflect the work and thoughts of the authors and are published herein as submitted. The publisher is not responsible for the validity of the information or for any outcomes resulting from reliance thereon.

Please use the following format to cite material from these proceedings:

Author(s), "Title of Paper," in Technologies for Optical Countermeasures XIII, edited by David H. Titterton, Robert J. Grasso, Mark A. Richardson, Proceedings of SPIE Vol. 9989 (SPIE, Bellingham, WA, 2016) six-digit Article CID Number.

ISSN: 0277-786X

ISSN:1996-756X (electronic)

ISBN: 9781510603820

ISBN: 9781510603837 (electronic)

Published by

SPIE

P.O. Box 10, Bellingham, Washington 98227-0010 USA

Telephone +1 3606763290 (Pacific Time) · Fax +1 3606471445

SPIE.org

Copyright (C) 2016, Society of Photo-Optical Instrumentation Engineers.

Copying of material in this book for internal or personal use, or for the internal or personal use of specific clients, beyond the fair use provisions granted by the U.S. Copyright Law is authorized by SPIE subject to payment of copying fees. The Transactional Reporting Service base fee for this volume is $\$ 18.00$ per article (or portion thereof), which should be paid directly to the Copyright Clearance Center (CCC), 222 Rosewood Drive, Danvers, MA 01923. Payment may also be made electronically through CCC Online at copyright.com. Other copying for republication, resale, advertising or promotion, or any form of systematic or multiple reproduction of any material in this book is prohibited except with permission in writing from the publisher. The CCC fee code is 0277-786X/16/\$18.00.

Printed in the United States of America.

Publication of record for individual papers is online in the SPIE Digital Library.

\section{SPIE. DIGITAL \\ SPIEDigitallibrary.org}

Paper Numbering: Proceedings of SPIE follow an e-First publication model. A unique citation identifier (CID) number is assigned to each article at the time of publication. Utilization of CIDs allows articles to be fully citable as soon as they are published online, and connects the same identifier to all online and print versions of the publication. SPIE uses a six-digit CID article numbering system structured as follows:

- $\quad$ The first four digits correspond to the SPIE volume number.

- $\quad$ The last two digits indicate publication order within the volume using a Base 36 numbering system employing both numerals and letters. These two-number sets start with $00,01,02,03,04,05,06,07,08,09,0 A, 0 B \ldots$. 0Z, followed by 10-1Z, 20-2Z, etc. The CID Number appears on each page of the manuscript. 


\title{
Contents
}

\author{
$\checkmark \quad$ Authors \\ vii Conference Committee \\ ix Introduction
}

\section{LASERS AND SOURCES}

998907 UK industrial high-power fiber lasers [9989-26]

THREATS, THREAT DETECTION AND DISCRIMINATION

998908 Optics detection and laser countermeasures on a combat vehicle (Invited Paper) [9989-6]

998909 Modelling ultraviolet threats (Invited Paper) [9989-25]

\section{QUANTUM CASCADE LASERS}

9989 OB Design issues and physics for power scaling of quantum-cascade lasers (Invited Paper) [9989-7]

9989 0C Anti-aliasing techniques for signal verification and sensor integrity (Invited Paper) [9989-8]

9989 OD System physics modeling of the electro-optical energy conversion in mid-infrared quantum cascade lasers [9989-9]

\section{COUNTERMEASURE SYSTEMS}

9989 OE Towards low-cost infrared imagers: how to leverage Si IC ecosystem (Invited Paper) [9989-10]

9989 OF Electro-optic product design for manufacture: where next? (Invited Paper) [9989-1 1]

\section{ATMOSPHERIC EFFECTS}

$9989 \mathrm{OH}$ Temporal extension of phase screen sequences using proper orthogonal decomposition [9989-13]

9989 Ol Identification, regression and validation of an image processing degradation model to assess the effects of aeromechanical turbulence due to installation aircraft [9989-14] 


\section{LASER EFFECTS}

9989 0J Visible laser dazzle (Invited Paper) [9989-15]

9989 OK Using a CO2 laser for PIR-detector spoofing (Invited Paper) [9989-16]

9989 OM Concept of a human eye camera to assess laser dazzling interaction [9989-17]

9989 ON Evaluation of protection measures against laser dazzling for imaging sensors [9989-18]

MODELLING AND SIMULATION

9989 OP Updates on measurements and modeling techniques for expendable countermeasures [9989-20]

POINTING AND BEAM CONTROL

9989 OR Setup of a beam control system for high power laser system at DLR [9989-21]

9989 OS Adaptive conversion of input beam with unsymmetrical intensity distribution to near diffraction-limited flattop beam based on dual phase-only liquid crystal spatial light modulators [9989-22]

POSTER SESSION

9989 OT Accuracy analysis of a mobile tracking system for angular position determination of flying targets [9989-23] 


\title{
Authors
}

Numbers in the index correspond to the last two digits of the six-digit citation identifier (CID) article numbering system used in Proceedings of SPIE. The first four digits reflect the volume number. Base 36 numbering is employed for the last two digits and indicates the order of articles within the volume. Numbers start with 00, 01, 02, 03, 04, 05, 06, 07, 08, 09, 0A, 0B...0Z, followed by 10-1Z, 20-2Z, etc.

\author{
Albertoni, Alessandro, ol \\ Aleksandrova, A., OB \\ Allard, Lars, 08 \\ Barr, John R. M., OF \\ Bodin, Johan, 08 \\ Bodrucki, F., OC \\ Börjesson, Per, 08 \\ Buske, IVo, OR, OT \\ Codemard, C. A., 07 \\ Eberle, Bernd, OJ, OM, ON \\ Edström, Sten, 08 \\ Flores, Y. V., OB \\ Forster, D., OJ \\ Fredriksson, Jan, 08 \\ Gignilliat, Robert, OP \\ Henriksson, Markus, $\mathrm{OH}$ \\ Hilton, Allan, OE \\ James, I., 09 \\ Jeffery, G., OF \\ Kischkat, J., OB \\ Klem, Ethan J. D., OE \\ Koerber, Michael, OM \\ Lindskog, Nils, 08 \\ Ma, Haotong, OS \\ MacDonald, M., OF \\ Masselink, W. T., OB \\ Miccoli, M., Ol \\ Münzhuber, Franz, OD \\ Persson, Håkan, 08 \\ Pettersson, Magnus, 08 \\ Qi, Bo, OS \\ Ren, Ge, OS \\ Riede, Wolfgang, OT \\ Ritt, Gunnar, OJ, ON \\ Schleijpen, Ric H. M. A., OK \\ Semtsiv, M. P., OB \\ Sjöqvist, Lars, $08, \mathrm{OH}$ \\ Taczak, Thomas M., OP \\ Tafuto, A., 01 \\ Temple, Dorota S., OE \\ Tepfer, Kathleen, OP \\ Tholl, Hans Dieter, OD \\ Tidström, Jonas, $\mathrm{OH}$ \\ Togna, F., Ol \\ Troughton, M., OF \\ Usai, A., 0 l \\ van Putten, Frank J. M., OK \\ Walther, Andreas, OR, OT \\ Wang, Sanhong, OS
}

Widén, Anders, 08

\author{
Wilson, Rebekah F., OP \\ Xie, Zongliang, OS \\ Zervas, M. N., 07 \\ Zhang, Guowen, OS
}




\title{
Conference Committee
}

\author{
Symposium Chairs
}

David H. Titterton, United Kingdom Defence Academy

(United Kingdom)

Symposium Co-chairs

Ric Schleijpen, TNO Defence, Security and Safety (Netherlands)

Karin Stein, Fraunhofer-Institut für Optronik, Systemtechnik und

Bildauswertung (Germany)

Stuart S. Duncan, Leonardo-Finmeccanica (United Kingdom)

Conference Chairs

David H. Titterton, United Kingdom Defence Academy

(United Kingdom)

Robert J. Grasso, EOIR Technologies (United States)

Mark A. Richardson, Cranfield University (United Kingdom)

Conference Programme Committee

Brian Butters, Meon Technology Limited (United Kingdom)

Marc Eichhorn, Institut Franco-Allemand de Recherches de SaintLouis (France)

Ian F. Elder, SELEX Galileo Ltd. (United Kingdom)

Markus Henriksson, FOl-Swedish Defence Research Agency

(Sweden)

David B. James, Cranfield University (United Kingdom)

Helena Jelinkova, Czech Technical University in Prague (Czech Republic)

Espen Lippert, Norwegian Defence Research Establishment (Norway)

Gerald C. Manke II, Naval Surface Warfare Center Crane Division

(United States)

Eric D. Park, Q-Peak, Inc. (United States)

Manijeh Razeghi, Northwestern University (United States)

Kenneth A. Sarkady, U.S. Naval Research Laboratory (United States)

Ric H. M. A. Schleijpen, TNO Defence, Security and Safety (Netherlands)

Dirk Peter Seiffer, Fraunhofer-Institut für Optronik, Systemtechnik und Bildauswertung (Germany)

Ove Steinvall, Swedish Defence Research Agency (Sweden)

Hans-Dieter Tholl, Diehl BGT Defence GmbH \& Co. KG (Germany)

Maria S. Willers, Denel Dynamics (South Africa) 
Cornelius J. Willers, Council for Scientific and Industrial Research

(South Africa)

\section{Session Chairs}

1 Keynote Session

Robert J. Grasso, EOIR Technologies (United States)

David H. Titterton, United Kingdom Defence Academy

(United Kingdom)

2 Lasers and Sources

David H. Titterton, United Kingdom Defence Academy

(United Kingdom)

Ian F. Elder, Leonardo-Finmeccanica (United Kingdom)

3 Threats, Threat Detection and Discrimination

Kenneth A. Sarkady, U.S. Naval Research Laboratory (United States)

4 Quantum Cascade Lasers

Hans-Dieter Tholl, Diehl BGT Defence GmbH \& Co. KG (Germany)

Eric D. Park, Q-Peak, Inc. (United States)

5 Countermeasure Systems

Eric D. Park, Q-Peak, Inc. (United States)

Robert J. Grasso, EOIR Technologies (United States)

6 Atmospheric Effects

Dorota S. Temple, RTI International (United States)

$7 \quad$ Laser Effects

Ove Steinvall, FOI-Swedish Defence Research Agency (Sweden)

Ric H. M. A. Schleijpen, TNO Defence, Security and Safety (Netherlands)

8 Modelling and Simulation

Stuart S. Duncan, Leonardo-Finmeccanica (United Kingdom)

9 Pointing and Beam Control

Ric H. M. A. Schleijpen, TNO Defence, Security and Safety

(Netherlands)

Robert J. Grasso, EOIR Technologies (United States) 


\section{Introduction}

This year's conference, at the Edinburgh International Conference Centre, was the thirteenth time this conference was held. Conducted over two days, it offered a full complement of papers pertinent to Infrared and Electro-Optical Countermeasures, Threat Detection and Warning, Lasers and Sources for IRCM/EOCM, Pointing and Beam Control, Threats and Threat Characteristics, and Laser and Atmospheric Effects. As in past conferences, we conducted our panel discussion debating the topic of, "Factors that Affect Installed IRCM System Performance." This discussion, which has been ongoing past several years, is very popular and always leads to some exceptionally interesting discussion and debate. It was also used as a precursor to a new session that will be commenced next year dealing specifically with external events that have a direct impact on IRCM/EOCM system performance once it is installed and operating on a platform.

The conference consisted of nine sessions specifically focused upon: Lasers and Sources; Threats, Threat Detection, and Discrimination; Quantum Cascade Lasers; Countermeasure Systems; Atmospheric Effects; Laser Effects; Modelling and Simulation, and; Pointing and Beam Control. There was also a poster session. Three exceptional keynote papers were presented which addressed: 1) "New Frontiers in Quantum Cascade Lasers: High-Power Solid-State Frequency Comb and Terahertz Sources at Room Temperature;" 2) "NATO EW Challenge for Platform Protection," and; 3) "Recent Progress in MWIR and LWIR Quantum Cascade Lasers."

In the following sessions there were many excellent invited and contributed presentations covering mid-IR quantum cascade and fibre laser development, detection of optics at range, threat modelling and simulation, countermeasure and electro-optic systems design for manufacture, atmospheric and laser effects, modelling and simulation, and pointing and beam control. We had an excellent poster paper on "Accuracy analysis of a mobile tracking system for angular position determination of flying targets." Of particular interest was our session on Laser Effects. Here, we had several exceptional papers on laser effects with concentration on visible laser dazzle and simulating the human eye to quantitatively assess laser dazzling system performance. There were several excellent papers dealing with "Experimental and Numerical Analysis of Propagation of High-Energy Beams," and "Helicopter Engine Exhaust Rotor Downwash Effects on Laser Beams." Both papers deal with what we get at the end of the propagation chain once the effects of rotor downwash, turbulence, and absorption and scattering take their toll on the otherwise perfect beam emanating from our system.

We wish to thank all of our presenters for delivering an outstanding conference; moreover, we also thank our Programme Committee for their continued support 
and willingness to chair the various sessions, which is also appreciated by SPIE. The chairmen encouraged the audience to consider topics for presentation and discussion at next year's conference and symposium, to be held in Warsaw, Poland.

David H. Titterton

Robert J. Grasso

Mark A. Richardson 